\title{
Diagnostic Values and Utility of Immunological, Morphological, and Molecular Methods for In Planta Detection of Phytophthora ramorum
}

\author{
L. F. F. Kox, I. R. van Brouwershaven, B. T. L. H. van de Vossenberg, \\ H. E. van den Beld, P. J. M. Bonants, and J. de Gruyter
}

First, second, third, fourth, and sixth authors: Plantenziektenkundige Dienst, P.O. Box 9102, 6700 HC Wageningen, The Netherlands; and fifth author: Plant Research International B.V., P.O. Box 16, 6700 AA Wageningen, The Netherlands. Accepted for publication 18 April 2007.

\section{ABSTRACT}

Kox, L. F. F., van Brouwershaven, I. R., van de Vossenberg, B. T. L. H., van den Beld, H. E., Bonants, P. J. M., and de Gruyter, J. 2007. Diagnostic values and utility of immunological, morphological, and molecular methods for in planta detection of Phytophthora ramorum. Phytopathology 97:1119-1129.

In this study, six methods for the detection of Phytophthora ramorum in planta were compared using naturally infested rhododendron plant material. The methods included two immunological methods, one an enzyme-linked immunosorbent assay (ELISA) and the other using a lateral flow format (LFD). Three molecular tests based on the polymerase chain reaction (PCR) using TaqMan chemistry also were assessed, including two assays designed for specific detection of $P$. ramorum and one designed for genus-level detection of Phytophthora. Isolation followed by morphological identification also was assessed. The diagnostic values of each of the methods, evaluated based on diagnostic sensitivity, diagnostic specificity, positive predictive value, and negative predictive value, were calculated based upon the test results from 148 field samples. The "gold standard" used for the calculations was the final diagnosis, which was based on either a positive PCR result or successful isolation of P. ramorum. The Phytophthora spp. TaqMan PCR, ELISA, and LFD had higher sensitivities than the $P$. ramorum-specific methods, which make them useful as prescreening methods, where positive results must be confirmed by PCR or isolation. The article discusses practical advantages and disadvantages of each of the methods and how they are valuable in the diagnostic process, according to the circumstances of use (that is, diagnosis or surveillance) and in relation to the prevalence of $P$. ramorum infestation in the population to be tested.

Additional keywords: analytical sensitivity, analytical specificity, DNA isolation, sudden oak death.
Phytophthora ramorum Werres, De Cock \& Man in 't Veld was first described as a new pathogen on Rhododendron spp. and Viburnum bodnantense ( $\times$ ) 'Dawn' in Europe (40). Initially, this new Phytophthora sp., first recorded in The Netherlands and Germany in 1993, was found incidentally and was not considered to be very harmful; this changed, however, when $P$. ramorum was identified as the causal agent of sudden oak death in California (30), where it is a serious pathogen of oak trees. As a result, the European Union (EU) enforced phytosanitary emergency measures in 2002 to prevent the introduction and spread of $P$. ramorum in the EU (9). The legislation includes regular inspections and eradication of infections in nurseries, trade with a plant passport of the most important host plant genera Rhododendron and Viburnum (Camellia was added in 2004), and surveys in parks. Since 2004, member states also are required to take appropriate measures in parks to prevent the spread of this organism (10). Rapid and accurate detection of $P$. ramorum is essential to implement early and adequate management measures. For diagnosis of $P$. ramorum, several methods based on morphology and molecular techniques recently have become available $(5,8,13-16,18,20,21,27,33,35$, 36,40).

Examination of morphological features depends on the isolation of the organism and requires a large amount of specialist knowledge. Isolation of $P$. ramorum is not always successful,

Corresponding author: L. F. F. Kox; E-mail address: 1.f.f.kox@minlnv.nl

doi:10.1094/PHYTO-97-9-1119

This article is in the public domain and not copyrightable. It may be freely reprinted with customary crediting of the source. The American Phytopathological Society, 2007. because recovery rates are linked to suitability of the sample, freshness of the material, type of host material, and time of the year (30). For example, isolations from trees or from samples taken during a dry season are difficult (14). Reduced viability and presence of competing organisms such as other Phytophthora spp. may inhibit isolation of $P$. ramorum (30). Furthermore, diagnosis based on isolation and morphological identification is time consuming and slow, taking 5 to 10 days.

Nucleic acid amplification via the polymerase chain reaction (PCR) also can be used to detect unviable organisms; therefore, it can be surmised that the rate of false negatives is much lower for this technique. This we showed in a previous study (20), in which the diagnostic sensitivity (proportion of true positives correctly identified by the test) of PCR was higher than that of culturebased morphological identification (92 and 78\%, respectively). Moreover, in contrast to morphological identification, PCR methods can be applied directly to the plant material without the need for culturing, making diagnosis possible on the day of receipt of the sample. Traditionally, PCR products are detected by agarose gel electrophoresis and ethidium bromide staining, which is laborious and time consuming. PCR also can be performed as real-time PCR where accumulation of PCR product is measured using fluorescence. Fluorescent detection of PCR products can be accomplished by use of either nonspecific DNA-binding of the fluorescent dye SYBR green or by sequence-specific hybridization with a fluorescent probe $(23,24)$. The higher the starting copy number of the nucleic acid target, the sooner a significant increase in fluorescence is observed. A significant increase in fluorescence above a threshold value indicates detection of accumulated PCR product. This real-time detection of PCR products further reduces the analysis time, enabling molecular identification within $3 \mathrm{~h}$. 
Furthermore, fluorescent detection of PCR products in real-time PCR assays makes this technique more suitable for automation and high throughput testing. Several real-time PCR methods have been developed for identification of $P$. ramorum using SYBR green $(5,14)$, TaqMan probes $(13,15,33,36)$, and molecular beacons (5). Real-time PCR technology also is suitable for on-site testing using portable real-time PCR equipment (35), although not for large-scale testing. Although PCR and isolation are the standard in diagnosis, these techniques are relatively expensive and depend on the availability of equipment and expertise.

A very cheap and simple immunological technique that allows large scale testing of Phytophthora spp. is the enzyme-linked immunosorbent assay (ELISA) available from Agdia, Elkhart, IN. This technique uses antibodies that recognize proteins that are unique to specific organisms. A variant in an immunochromatic format is the lateral flow device (LFD) available from Pocket Diagnostic (Central Science Laboratory [CSL], York, UK) $(6,22)$, providing results within $10 \mathrm{~min}$ and, therefore, particularly useful for on-site testing. Currently available ELISA and LFD kits are considered to detect all known Phytophthora spp., but also detect some Pythium spp. In spite of this cross-reactivity, these kits have been useful for detection of Phytophthora spp. (22,34). ELISA has a low detection limit and can detect the presence of Phytophthora spp. at lower population densities than dilution plating (12).

The United States Department of Agriculture, Animal and Plant Health Inspection Service, Plant Protection and Quarantine (USDA-APHIS-PPQ) encourages laboratories to use ELISA as a "prescreening" method, where only samples with a positive result are further tested by PCR and isolation (37). The intent of using ELISA as a prescreen is to reduce cost and the number of samples that need to be processed for subsequent tests. So far, no studies have been published where ELISA results are compared with those of isolation or PCR.

The overall objective of this study was to determine the diagnostic values of all types of assays currently in use for detection of $P$. ramorum, including ELISA (Agdia), lateral flow immunochromatography (Pocket Diagnostic) $(6,22)$, two TaqMan assays for detection of $P$. ramorum $(13,15)$, and isolation followed by

TABLE 1. Isolates of Phytophthora and Pythium spp. used for assessment of analytical specificity of the Phytophthora spp. TaqMan assay

\begin{tabular}{|c|c|c|c|}
\hline Species & Isolate code ${ }^{a}$ & Geographic origin & Host or substrate \\
\hline \multicolumn{4}{|l|}{ Phytophthora spp. } \\
\hline Phytophthora alni & BRAS 28, PD 2001/9544 & Unknown & Alnus \\
\hline P. arecae & CBS 306.62, ATCC 64710, IMI 062656 & India & Areca catechu \\
\hline P. bisheria & CBS 253.93, PD 90/444-1 & The Netherlands & Rosa sp. \\
\hline P. brassica & CBS 179.87 & The Netherlands & Brassica oleracea \\
\hline P. cactorum & PD $88 / 15$ & The Netherlands & Fragaria $\times$ ananassa \\
\hline P. cactorum & P6183, PRI 63 & New York, Unites States & Rubus idaeus \\
\hline P. cactorum $\times$ hedraiandra ${ }^{\mathrm{b}}$ & CBS 113348, PD 2002/5453-1 & The Netherlands & Rhododendron sp. \\
\hline P. cactorum $\times$ hedraiandra ${ }^{\mathrm{b}}$ & CBS 100427, PD 95/5111 & Unknown & Idesia polycarpa. \\
\hline P. cactorum $\times$ hedraiandra ${ }^{\mathrm{b}}$ & PD 2001/8446-2, PRI 697 & The Netherlands & Rhododendron sp. \\
\hline P. cactorum $\times$ nicotianae & PD 94/1166 & The Netherlands & Spatiphyllum sp. \\
\hline P. cambivora & CBS 376.61, PRI 459 & Poland & Andromeda floribunda \\
\hline P. cambivora & BRAS 13, PD 2001/9509 & Unknown & Fagus sp. \\
\hline P. capsici & PD 92/989 & The Netherlands & Cyclamen sp. \\
\hline P. capsici & CBS 370.72, ATCC 15399, PD 06/03209184 & New Mexico, United States & Capsicum aппиит \\
\hline P. cinnamomi & PD 93/1397 & Germany & Calluna sp. \\
\hline P. cinnamomi & CBS 144.22, ATCC 1407, IMI 022938, PRI 393 & Indonesia & Cinnamomum burmannii \\
\hline P. citricola & P7008, PD AN 96/15, PRI 430 & California, Unites States & Medicago sativa \\
\hline P. citricola & CBS 181.25, ATCC 64532, IMI 077970, PD 06/03209133 & Unknown & Pinus resinosa \\
\hline P. citrophthora & CBS 289.35, PRI 443 & Unknown & Citrus paradisi \\
\hline P. citrophthora & CBS 274.33, PD 06/03209125 & Cyprus & Citrus limonium \\
\hline P. cryptogea & PD 2001/7699, BBA 63651, PRI 475 & Germany & Begonia sp. \\
\hline P. cryptogea & CBS 308.62, ATCC 15402, IMI 325907, PD 06/03209053 & United States & Aster sp. \\
\hline P. cryptogea-drechsleri complex & PD 04/02125632 & The Netherlands & Helleborus sp. \\
\hline P. drechsleri & PD 98/9681, PRI 405 & The Netherlands & Hedera helix \\
\hline P. drechsleri & BBA 62679, PD 2003/2152 & Unknown & Unknown \\
\hline P. erythroseptica & CBS 129.23, IMI 034684 & Ireland & Solanum tuberosum \\
\hline P. fragariae var. fragariae & BRASS 22, PD 2001/19546 & Unknown & Fragaria sp. \\
\hline P. fragariae var. rubi & CBS 967.95, ATCC 90442, IMI 355974 & Scotland, United Kingdom & Rubus idaeus \\
\hline P. gonapodyides & CBS 554.67, ATCC 60351, PRI 395 & Unknown & Unknown \\
\hline P. gonapodyides & PD 2001/16744 & Unknown & Unknown \\
\hline P. hedraiandra & PD 2001/7520 & The Netherlands & Viburnum sp. \\
\hline P. humicola & CBS 200.81, ATCC 52179 & Taiwan & Soil from citrus orchard \\
\hline P. ilicis & PD $91 / 595$ & The Netherlands & Ilex agrefolium \\
\hline P. infestans & VK 98014 & Unknown & Unknown \\
\hline P. inflata & IMI 342899 & Unknown & Unknown \\
\hline P. inundata & CBS 216.85 & The Netherlands & Zostera marina \\
\hline P. kernoviae & cc2286, PRI 712 & United Kingdom & Rhododendron ponticum \\
\hline P. kernoviae & cc2300, PRI 713 & United Kingdom & R. ponticum \\
\hline P. kernoviae & cc2306, PRI 714 & United Kingdom & Magnolia sp. \\
\hline P. kernoviae & cc2378, PRI 715 & United Kingdom & R. ponticum \\
\hline
\end{tabular}

a Isolate codes. ATCC = American Type Culture Collection; BBA = Biologische Bundesanstalt, Germany; BRAS = Clive Brasier, Forest Research Agency, Farnham, UK; CBS = Centraal Bureau voor Schimmelcultures, Utrecht, The Netherlands; $c c=$ Central Science Laboratory, York, UK; GZ = Grazyna Szkutka, State Plant Health and Seed Inspection Service, Torun, Poland; IMI = International Mycological Institute, Engham, UK; N = Plant Research International, Wageningen, The Netherlands; P = University of California, Riverside, CA; PD = Plant Protection Service, Wageningen, The Netherlands; and PRI = Plant Research International, Wageningen, The Netherlands.

${ }^{\mathrm{b}}$ Recently described hybrid (26).

c Proposed to be "intermediate species" linking the genera Pythium and Phytophthora $(28,38)$.

d Proposed to be "intermediate species" linking the genera Pythium and Phytophthora (38), reclassified as Phytophthora undulata by Dick (7) on the basis of zoospore differentiation and ribosomal DNA analysis. 
morphological examination. A newly developed TaqMan assay designed for genus-level detection of Phytophthora spp. was included in the method comparison. One of the more specific aims of this study was to validate this new assay. This method could be an attractive alternative for immunological prescreening methods. Its additional value compared with immunological methods is that identification of the species can be accomplished directly by sequence analysis of the PCR product. Both TaqMan assays for detection of $P$. ramorum were compared, in more detail, including two different DNA isolation methods. The diagnostic values (diagnostic sensitivity and specificity and positive and negative predictive values) of each of the assays were calculated on the basis of test results with 148 plant samples collected in the field.

\section{MATERIALS AND METHODS}

DNA isolation from fungal cultures. The Phytophthora and Pythium isolates that were used for assessing the analytical specificity of Phytophthora spp. TaqMan assay are listed in Table 1. Isolates were grown in the dark for 10 to 14 days at $20^{\circ} \mathrm{C}$ in pea broth $(11,21)$. Mycelium was harvested and lyophilized, and total DNA was extracted using the Puregene Genomic DNA Isolation kit from Gentra (BIOzymTC, Landgraaf, The Netherlands) or the Wizard Magnetic DNA Purification System for Food (Promega, Leiden, The Netherlands) according to the manufacturer's instructions. The DNA pellet was dissolved in $100 \mu \mathrm{l}$ of Tris-EDTA (10 mM Tris- $\mathrm{HCl}, \mathrm{pH} 8.0$, and $1 \mathrm{mM}$ EDTA). The DNA solutions were diluted to a DNA concentration of $5 \mathrm{ng} / \mu \mathrm{l}$. Amplifications were performed with $1 \mu \mathrm{l}(5 \mathrm{ng})$ of fungal DNA.

Samples. Samples from 111 Rhododendron ponticum plants with disease symptoms of $P$. ramorum (40) were collected from two sites in the Netherlands known to be infested: a monastery in Nijmegen $(n=74)$ and a private garden in Ede $(n=37)$. Samples also were taken from 37 healthy $R$. catawbiense plants maintained at the greenhouse of the Diagnostic Department of the Plant Protection Service (PPS), Wageningen, The Netherlands. The samples were collected in August and September 2005. Each sample consisted of five leaves or five stems taken from one plant (one sample per plant). Symptomatic tissue was excised from the periphery of lesions with a sterile scalpel. Symptomatic and healthy plant parts

TABLE 1. (continued from preceding page)

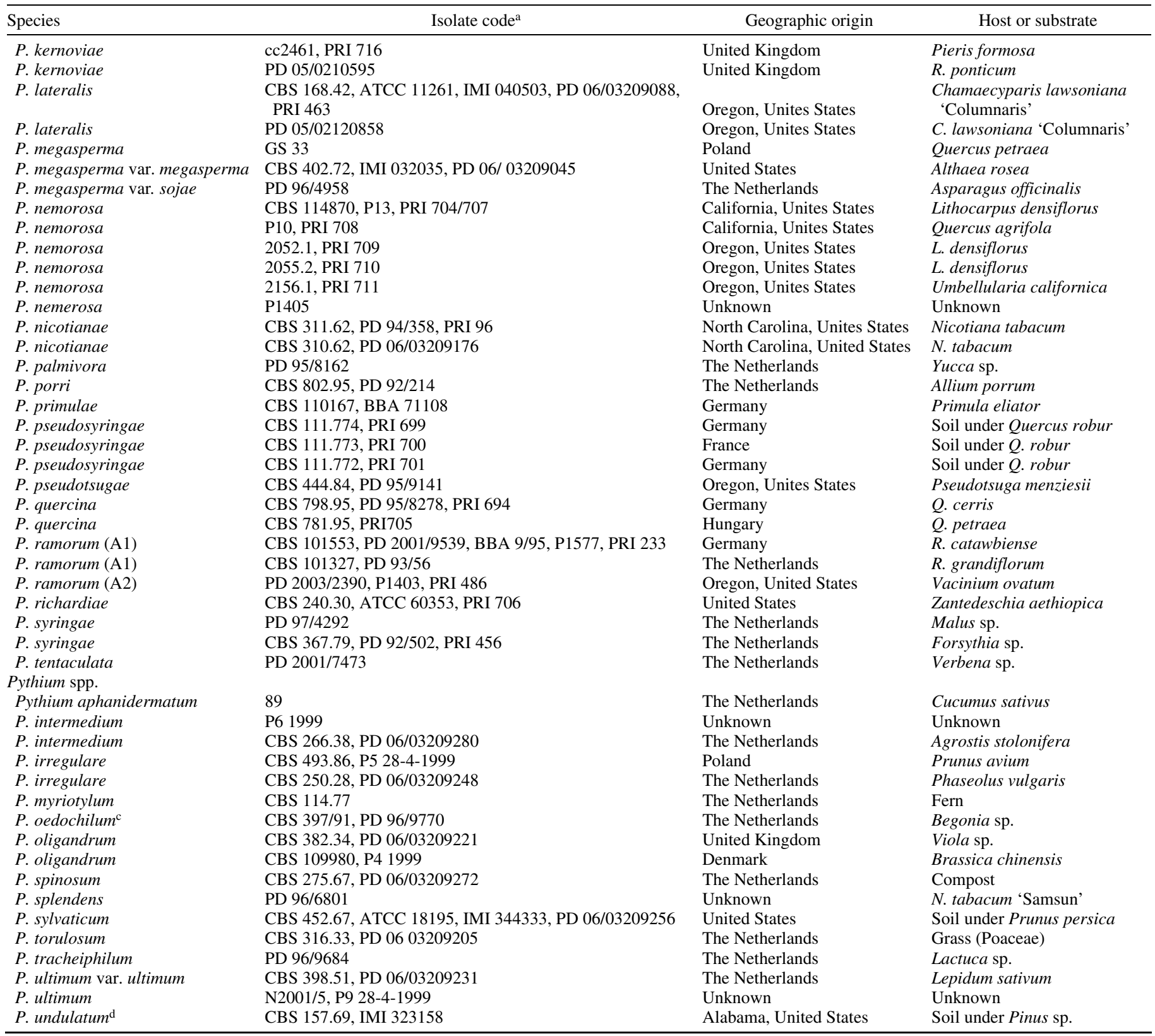


were rinsed in tap water for $10 \mathrm{~s}$ and cut into $\approx 0.1-\mathrm{cm}^{2}$ pieces with a sterile scalpel. For each plant sample, the plant pieces were mixed and distributed in several test samples (as described below) so that each test sample represents five plant parts. Total surface areas of 3 and $1 \mathrm{~cm}^{2}\left(1 \mathrm{~cm}^{2}\right.$ corresponds to $\left.30 \mathrm{mg}\right)$ were collected for testing with the LFD (Pocket Diagnostic) and ELISA (Phytophthora PathoScreen kit; Agdia), respectively. The remaining plant pieces were rinsed with $50 \%$ ethanol followed by tap water, and 20 pieces (total surface area $2 \mathrm{~cm}^{2}$ ) were collected for incubation on four agar plates (five pieces per agar plate). The remainder of the plant pieces was rinsed with $1 \%$ sodium hypochlorite followed by tap water. Two test samples with a total surface area of $1 \mathrm{~cm}^{2}$ each were collected for DNA isolation. One was used for immediate DNA isolation using two different methods; the duplicate sample was kept at $-20^{\circ} \mathrm{C}$ as reference material.

LFD. Pocket Diagnostic lateral flow test kits, each containing a, LFD for detection of Phytophthora spp. and a bottle with $5 \mathrm{ml}$ of extraction solution and five stainless steel ball bearings, were purchased from CSL. The antibodies used in the LFD were supplied by Neogen Corporation (Lansing, MI). Testing was performed according to the manufacturer's instructions. Briefly, plant pieces with a total surface area of $3 \mathrm{~cm}^{2}(90 \mathrm{mg})$ were placed in the extraction bottle and the bottle was shaken vigorously for $60 \mathrm{~s}$ to give a well-mixed suspension. Two drops $(100 \mu \mathrm{l})$ of this suspension were put onto the LFD using a pipette and allowed to run along the membrane. Results were read 1 to 3 min after the appearance of the blue control line. The appearance of the blue test line indicated a positive test result and the test sample was considered to contain a Phytophthora spp.

ELISA. A double-antibody sandwich (DAS)-ELISA was performed with reagents from the Phytophthora PathoScreen Kit from Agdia according to the manufacturer's instructions. Plant pieces with a total surface area of $1 \mathrm{~cm}^{2}(30 \mathrm{mg})$ were placed in a 1.5-ml microcentrifuge tube with a secure fitting flattop cap (Superlock tubes; BIOzymTC) containing a stainless steel bead ( $3.97 \mathrm{~mm}$ in diameter) and $300 \mu \mathrm{l}$ of GEB2 buffer. The tube was placed in a bead mill (Mixer Mill MM300; Retsch GmbH, Haan, Germany) for $1.5 \mathrm{~min}$ at $1,800 \mathrm{beats} / \mathrm{min}$. The mixture was centrifuged for $1 \mathrm{~min}$ at $14,000 \times g$ and $100 \mu \mathrm{l}$ of the resulting supernatant was used for the DAS-ELISA. Positive and negative controls were a lyophilized positive control purchased from Agdia and RNAse- and DNAse-free water, respectively. Absorbencies were measured $1 \mathrm{~h}$ after addition of substrate using a microplate reader (Model 680; Bio-Rad, Veenendaal, The Netherlands). The negative controls should read between 0 and 0.05 ; the positive controls should read between 0.5 and 2.0. Samples with absorbance values $>0.5$ were considered positive for the presence of Phytophthora spp.

Culture. Five plant pieces (of $\approx 0.1 \mathrm{~cm}^{2}$ ) were placed on each of the following four plates: one water agar (1.5\% agar no. 1) (Oxoid, Haarlem, The Netherlands), two synthetic nutrient-poor agar (SNA) (11), and one cherry decoction agar (CHA) (11). The plates were checked for growth of Phytophthora spp. after 5 to 10 days of incubation at $20^{\circ} \mathrm{C}$ in darkness. If a Phytophthora sp. was observed, its species was identified according to morphological features.

DNA isolation. Plant pieces with a total surface area of $1 \mathrm{~cm}^{2}$ $(30 \mathrm{mg})$ were placed in a $1.5-\mathrm{ml}$ microcentrifuge tube with a secure fitting flattop cap (Superlock tubes; BIOzymTC) containing a stainless steel bead $(3.97 \mathrm{~mm}$ in diameter) and $300 \mu \mathrm{l}$ of extraction buffer $(0.02 \mathrm{M}$ phosphate-buffered saline, $0.05 \%$ Tween $\mathrm{T} 25,2 \%$ polyvinylpyrrolidone, and $0.2 \%$ bovine serum albumin). The tube was placed in a bead mill (Mixer Mill MM300; Retsch) for $80 \mathrm{~s}$ at 1,800 beats/min. The mixture was centrifuged for $5 \mathrm{~s}$ at maximum speed in a microcentrifuge $(16,100 \times g)$ and $75 \mu \mathrm{l}$ of the resulting supernatant (i.e., plant sap) was used for DNA isolation.
DNA was isolated using the reagents of the Qiagen DNeasy Plant Mini Kit (Westburg, Leusden, The Netherlands) according to the manufacturer's instructions. The DNA was eluted in $50 \mu \mathrm{l}$ of elution buffer and further purified using polyvinylpolypyrrolidone (PVPP) (Sigma, Zwijndrecht, The Netherlands) columns. The columns were prepared by filling Axygen Multi-Spin columns (Dispolab, Asten, The Netherlands) with $0.5 \mathrm{~cm}$ of PVPP, placing it on an empty reaction tube, and washing twice with $250 \mu \mathrm{l}$ of DNAse- and RNAse-free water by centrifuging the column for $5 \mathrm{~min}$ at $4,000 \times g$. The DNA suspension was applied to a PVPP column and centrifuged for $5 \mathrm{~min}$ at $4,000 \times \mathrm{g}$. The flow-through fraction was used as input for the TaqMan assays.

Automated DNA isolation was performed with the KingFisher 96 magnetic particle processor (Thermo Electron Corporation, Breda, The Netherlands) using the QuickPick Plant DNA kit from Bio-Nobile (Isogen Life Science, IJsselstein, The Netherlands) according to a protocol developed by the manufacturer (K. Kontu, personal communication). Briefly, $5 \mu \mathrm{l}$ of proteinase $\mathrm{K}$ and $50 \mu \mathrm{l}$ of lysis buffer were added to $75 \mu \mathrm{l}$ of the plant sap described above. After $30 \mathrm{~min}$ of incubation at $65^{\circ} \mathrm{C}, 5 \mu \mathrm{l}$ of MagaZorb Magnetic Particles and $125 \mu \mathrm{l}$ of binding buffer were added. The particle-bound DNA was washed twice with $200 \mu$ of wash buffer and DNA was eluted in $50 \mu$ of elution buffer. The DNA was further purified using a PVPP column as described above.

Each series of DNA extractions included multiple external controls: a negative control (DNAse- and RNAse-free water), one per five samples, to monitor false positives caused by cross contamination during DNA isolation, and a positive control to check efficiency of nucleic acid isolation. The positive controls were aliquots of a batch of sap from known $P$. ramorum-infected plant tissue, prepared in the same manner as the samples.

TaqMan assays. All TaqMan assays are based on sequences in the nuclear ribosomal internal transcribed spacer (ITS) region. Oligonucleotides that were used as primers and probes in the PCR are listed in Table 2. Primers were obtained from Isogen Life Science or Eurogentec (Seraing, Belgium). 6-Carboxy-tetramethyl-rhodamine (TAMRA) probes were obtained from Applied Biosystems (Nieuwerkerk aan de IJssel, The Netherlands). Minor groove-binding nonfluorescent quencher (MGB-NFQ) probes were obtained from Applied Biosystems. All reactions were performed in 0.2-ml optical grade plates (Applied Biosystems) in an ABI PRISM 7900HT or 7500 Sequence Detection System (Applied Biosystems).

The Phytophthora spp. TaqMan assay was performed using the reagents from the qPCR Core Kit from Eurogentec. The 25- $\mu 1$ reaction mixture contained reaction buffer with ROX passive reference, $0.4 \mu \mathrm{M}$ each primer FITS_15Ph and RITS_279Ph, $0.132 \mu \mathrm{M}$ probe all_phy, $200 \mu \mathrm{M}$ dNTP/dUTP mix, $5 \mathrm{mM} \mathrm{MgCl} 2$, 0.625 units of HotGoldStar Taq DAN polymerase, and $1 \mu \mathrm{l}$ of DNA isolated from the fungal cultures $(5 \mathrm{ng} / \mu \mathrm{l})$ (Table 1) or plant (unknown concentration). The cycling conditions were $2 \mathrm{~min}$ at $50^{\circ} \mathrm{C}, 10 \mathrm{~min}$ at $95^{\circ} \mathrm{C}$, and 40 cycles at $95^{\circ} \mathrm{C}$ for $15 \mathrm{~s}$ and $60^{\circ} \mathrm{C}$ for $1 \mathrm{~min}$. The threshold value was set at a fluorescence $(\Delta \mathrm{Rn})$ of 0.1 . A cycle threshold $(\mathrm{Ct})$ (the PCR cycle where the fluorescent signal exceeds that of the threshold value) $<35$ was scored as a positive result. Where appropriate, PCR products obtained with the Phytophthora spp. TaqMan assay were sequenced to confirm amplification and to determine the species. The $P$. ramorumspecific TaqMan assays developed at CSL (15) and the University of California, Berkeley (UCB) (13) were performed using the $2 \times$ concentrated TaqMan Universal Master Mix (Applied Biosystems). The 25- $\mu$ l reaction mixture of the CSL TaqMan assay contained TaqMan Universal PCR Master Mix, 0.9 $\mu \mathrm{M}$ each primer Pram-114Fc and Pram-190R, $0.3 \mu \mathrm{M}$ probe Pram probe, and $5 \mu \mathrm{l}$ of DNA isolated from the plant. Cycling conditions were $10 \mathrm{~min}$ at $94^{\circ} \mathrm{C}$ and 40 cycles at $94^{\circ} \mathrm{C}$ for $15 \mathrm{~s}$ and $60^{\circ} \mathrm{C}$ for 1 min. The threshold value was set at a $\Delta \mathrm{Rn}$ value of 0.04 . A $\mathrm{Ct}<35$ was scored as a positive result. The $15-\mu$ reaction mixture of the 
UCB TaqMan assay contained TaqMan Universal PCR Master Mix, $0.2 \mu \mathrm{M}$ each primer Pram-5 and Pram-6, $0.2 \mu \mathrm{M}$ probe Pram-7, and $5 \mu \mathrm{l}$ of DNA isolated from the plant. Cycling conditions were $3 \mathrm{~min}$ at $95^{\circ} \mathrm{C}$ and 40 cycles at $95^{\circ} \mathrm{C}$ for $15 \mathrm{~s}$ and $60.5^{\circ} \mathrm{C}$ for $1 \mathrm{~min}$. The threshold was set at a $\Delta \mathrm{Rn}$ value of 0.2 . A $\mathrm{Ct}<35$ indicated a positive result. In the original publications of the CSL and UCB $P$. ramorum TaqMan assays, Ct cutoff values were set at 36 and 40 , respectively $(13,15)$. To avoid potentially false-positive results, we have interpreted the TaqMan data conservatively by using an arbitrary Ct cutoff of 35 .

Similar to each series of DNA extraction, each series of amplification reactions included external controls: a negative control (DNAse- and RNAse-free water) to test for contamination with DNA as well as a positive control (DNA from a reference strain of the pathogen) to monitor the performance of the PCR. The positive controls should have $\mathrm{Cts}<35$ and the negative controls should have $\mathrm{Cts}$ of 40 . Because the negative controls are monitoring contamination they are assessed at a higher $\mathrm{Ct}$ threshold than the positive controls. The assessment of $\mathrm{Ct}$ values in the range of 35 to 40 enables early tracking of contamination.

In addition to the external positive and negative controls for DNA extraction and amplification, two types of internal positive controls (giving information regarding the efficiencies of nucleic acid isolation and amplification, respectively, in each individual sample) were used. False negatives due to inefficient DNA extraction were monitored using an internal TaqMan assay control based on exogenous DNA: a conserved region in the plant cytochrome oxidase (COX) gene (39). The $25-\mu$ l reaction mixture contained TaqMan Universal Master Mix (Applied Biosystems), $0.3 \mu \mathrm{l}$ of each primer COX-F (5'-CGTCGCATTCCAGATTATCCA-3') and COX-RW (5'-CAACTACGGATATATAAGRRCCRRAACTG-3'), $0.1 \mu \mathrm{M}$ COX probe (5'-VIC-AGGGCATTCCATCCAGCGTAAGCA-TAMRA-3'), and $2 \mu \mathrm{l}$ of DNA isolated from the plant. Cycling conditions were $10 \mathrm{~min}$ at $94^{\circ} \mathrm{C}$ and 40 cycles at $94^{\circ} \mathrm{C}$ for $15 \mathrm{~s}$ and $60^{\circ} \mathrm{C}$ for $1 \mathrm{~min}$. The threshold was set automatically. Samples with a $\mathrm{Ct}<35$ were scored as positive. To monitor false negatives resulting from inhibition of the amplification reactions, duplicate reactions of the UCB $P$. ramorum TaqMan assay were spiked with $0.25 \mathrm{fg}$ of exogenous DNA: a plasmid (pGEM-T Easy) containing the P. ramorum PCR product amplified with primers Phyto1 and Phyto 4 (Table 2).

Cloning of ITS sequences in pGEM-T Easy. To provide exogenous DNA for spiking amplification reactions, PCR product amplified with primers Phyto 1 and Phyto 4 (Table 2) from $P$. ramorum isolate CBS 101330 (PD 98/5233) (21,40) was cloned into the pGEM-T Easy vector (Promega) according to standard procedures (32). Plasmid DNA was isolated using the Qiagen Plasmid Mini Kit.

Conventional PCR assays. The 50- $\mu$ l reaction mixture was composed as follows: $0.2 \mu \mathrm{M}$ each primer Phyto 1 and Phyto 4
(Table 2) or universal fungal primers ITS1 and ITS4 (41) (Table 2), $200 \mu \mathrm{M}$ dNTPs (Promega), 0.5 units of HotStarTaq DNA polymerase (Qiagen), reaction buffer (with $1.5 \mathrm{mM} \mathrm{MgCl}_{2}$ ) (Qiagen), and $5 \mu \mathrm{l}$ of template DNA. The PCR was performed in a 96-well Peltier-type thermocycler (PTC-200; MJ Research: BIOzymTC) with the following parameters: $15 \mathrm{~min}$ at $95^{\circ} \mathrm{C} ; 35$ cycles of $15 \mathrm{~s}$ at $94^{\circ} \mathrm{C}, 60 \mathrm{~s}$ at $62^{\circ} \mathrm{C}$, and $45 \mathrm{~s}$ at $72^{\circ} \mathrm{C}$; followed by a final extension for $10 \mathrm{~min}$ at $72^{\circ} \mathrm{C}$ and quickly cooled to room temperature. After amplification, $5 \mu$ l of the PCR products were electrophorized on a $1.5 \%$ agarose gel according to standard methods (32) along with a 100-bp DNA ladder (GeneRuler 100-bp DNA Ladder; Fermentas GmbH, St. Leon-Rot, Germany) to size fragments. PCR products were viewed and photographed under UV light.

Sequencing. Sequencing reactions were performed directly with purified PCR products using the Big Dye Terminator Kit (Applied Biosystems) with the primers FITS_15Ph and RITS_279Ph (Table 2) according to the manufacturer's protocol. Sequencing samples were analyzed on an ABI PRISM 3100 Genetic Analyzer (Applied Biosystems). The PCR products were sequenced in both directions. Contig assembly as well as the final alignment of consensus sequences was performed using the SeqMan and MegAlign modules of the Lasergene software (DNAstar, Inc., Madison, WI).

Precautions to prevent DNA contamination. Prevention of contamination was accomplished by physical separation of the different steps in the PCR procedure, using different pipettes (with aerosol-resistant pipette tips) (self-sealing noncollapsing [SSNC] filter tips, BIOzymTC), and wearing separate coats and gloves in each of the three laboratories used. One laboratory was used for preparing reaction mixes, one for the nucleic acid extraction, and one for the analysis of PCR products. The workflow was organized in a way that contamination risk was minimized. Chemical decontamination of surfaces and equipment was performed with $1 \%$ sodium hypochlorite $(29,31)$.

Interpretation of TaqMan results. The results of each series of $P$. ramorum and Phytophthora spp. TaqMan assays were considered to be reliable if all negative and positive controls in each series gave the expected results (positive results for positive controls and negative results for negative controls). In case the results of the controls were not as expected, the following procedures were followed. If the positive amplification control gave a negative result, a technical failure (e.g., omission of one of the components of the reaction mix) had occurred and the TaqMan assay was repeated. If the positive DNA isolation control gave a negative result, there was a failure in the DNA extraction procedure and the TaqMan assay was repeated with DNA extracted from the duplicate sample. If both the TaqMan assay and the internal COX control gave a negative result, but the spiked sample gave a positive result, presumably due to DNA of insufficient

TABLE 2. Oligonucleotides based on ribosomal internal transcribed spacer (ITS) regions used for detection of Phytophthora and Pythium spp.

\begin{tabular}{|c|c|c|c|c|c|}
\hline Oligonucleotide & Sequence $\left(5^{\prime} \text { to } 3^{\prime}\right)^{\mathrm{a}}$ & Orientation & Position $^{b}$ & Target & Reference \\
\hline Pram-5 & TTA GCT TCG GCT GAA CAA TG & Forward & $628-647$ & Phytophthora ramorum & 13 \\
\hline Pram-6 & CAG CTA CGG TTC ACC AGT CA & Reverse & $701-682$ & $P$. ramorum & 13 \\
\hline Pram-7 & FAM-ATG CTT TTT CTG CTG TGG CGG TAA-TAMRA & Forward & $658-681$ & P. ramorum & 13 \\
\hline Phyto 1 & CAT GGC GAG CGC TTG A & Forward & $125-140$ & P. ramorum & 13 \\
\hline Phyto 4 & GAA GCC GCC AAC ACA AG & Reverse & $811-794$ & P. ramorum & 13 \\
\hline Pram-114Fc & TCA TGG CGA GCG CTG GA & Forward & $124-140$ & P. ramorum & 15 \\
\hline Pram-190R & AGT ATA TTC AGT ATT TAG GAA TGG GTT TAA AAA GT & Reverse & $200-166$ & P. ramorum & 15 \\
\hline Pram probe & FAM-TTC GGG TCT GAG CTA GTA G-TAMRA & Forward & $144-162$ & P. ramorum & 15 \\
\hline FITS_15Ph & TGC GGA AAG GAT CAT TAC CAC ACC & Forward & $15-37$ & Phytophthora & This study \\
\hline RITS_279Ph & GCGAGCCTAGACATCCACTG & Reverse & $263-245$ & Phytophthora & This study \\
\hline All-phy & FAM-TTG CTA TCT AGT TAA AAG CA -MGBNFQ & Reverse & $219-240$ & Phytophthora & This study \\
\hline ITS 1 & TCC GTA GGT GAA CCT GCG G & Forward & $1-19$ & Fungus & 41 \\
\hline ITS4 & TCC TCC GCT TAT TGA TAT GC & Reverse & $898-887$ & Fungus & 41 \\
\hline
\end{tabular}

a Abbreviations: FAM = 6-carboxyfluorescein, TAMRA = 6-carboxytetramethylrhodamine, and MGBNFQ = minor groove-binding nonfluorescent quencher.

b Nucleotide position in GenBank accession code DQ168873. 
quantity or quality, then the TaqMan assay was repeated with DNA extracted from the duplicate sample. If the TaqMan assay gave a negative result for both the sample and the spiked sample (and, as a consequence, also the internal COX control), inhibitors of the DNA polymerase were present in the DNA and the TaqMan assay was repeated with 10-fold diluted DNA extract. If one of the negative controls was positive, a contamination had occurred and the TaqMan assay had to be repeated with DNA extract from the duplicate sample. An extensive review regarding the use of positive and negative controls and their interpretation has been published previously (19).

Analysis of test results. The diagnostic ability of each test was quantified by calculating diagnostic sensitivity and diagnostic specificity. In diagnostic practice, only the test result is known. We wanted to know how reliable the test was at predicting the presence of $P$. ramorum. We wanted to determine what proportion of plants with positive test results was truly positive. Therefore, we used predictive values. The following definitions were used: analytical sensitivity $=$ smallest detectable amount of target (= detection limit); analytical specificity $=$ ability of a test to identify the target from nontarget giving a measure of crossreactivity to nontarget; diagnostic sensitivity $=$ proportion of true positives correctly identified by the test (= probability that the test gives a positive result when the disease is present); diagnostic specificity $=$ proportion of true negatives correctly identified by the test (= probability that the test gives a negative result when the disease is not present); positive predictive value (PPV) = proportion of the samples with positive test result correctly identified by the test (= probability of disease when the test is positive); negative predictive value $(\mathrm{NPV})=$ proportion of the samples with negative test result correctly identified by the test (= probability of not having the disease when the test is negative); and prevalence $=$ proportion of cases of the disease $(2,3)$. Positive and negative predictive values depend on the prevalence of the disease in the population in which the test is applied. Therefore, prevalence-dependent predictive values were calculated according to Bayes's theorem (1) using the following equations: PPV = diagnostic sensitivity $\times$ prevalence/([diagnostic sensitivity $\times$ prevalence $]+[(1-$ diagnostic specificity $) \times(1$-prevalence $)])$ and NPV $=$ diagnostic specificity $\times(1-$ prevalence $) /([(1-$ diagnostic sensitivity) $\times$ prevalence $]+[$ diagnostic specificity $\times(1-$ prevalence $)]$.

To be able to calculate diagnostic values, a reference or "gold standard" is necessary to determine which samples are considered to contain $P$. ramorum (true positive samples). According to the diagnostic protocol of the European and Mediterranean Plant Protection Organization (EPPO) (8) and USDA-APHIS recommendations (37), both a positive culture result and a positive PCR result for $P$. ramorum are considered to be a positive final diagnosis.

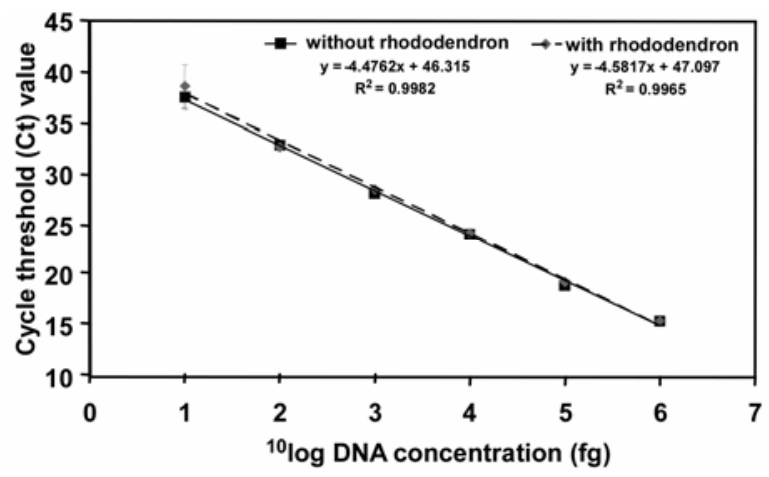

Fig. 1. Standard curve of cycle threshold $(\mathrm{Ct})$ values calculated from serial dilutions of DNA from Phytophthora ramorum isolate CBS 101553 amplified using the Phytophthora spp. TaqMan assay. Ct values shown are mean values for triplicate reactions; error bars represent standard deviations.
Proportions were calculated for each method and compared with Fisher's exact test using the GenStat statistical software (release 8.1; VSN International, Hemel Hempstead, UK). Fisher's exact test is an unbiased, uniformly most powerful test of independence in a two-by-two table (17). It tests the equality of two probabilities. In GenStat, the procedure Fisherexact was used to perform all pairwise tests of equality of the probability of the five methods $(r=5)$. Confidence intervals for means were calculated using standard methods (1). Differences in mean $\mathrm{Ct}$ values were tested using paired and unpaired Student's $t$ tests (1). Relative quantifications based on difference in $\mathrm{Ct}$ values were performed using the $2^{-\Delta \mathrm{C}^{\prime} \mathrm{t}}$ method (25).

\section{RESULTS}

Characteristics of the Phytophthora spp. TaqMan assay. To minimize the likelihood of nonspecific detection, the probe sequence was compared with sequences in the National Center of Biotechnology Information (NCBI) DNA database (GenBank) using the BLAST database search program (4). Only sequence homologies with Phytophthora spp. were found. The analytical specificity of the assay was assessed using DNA isolated from $P$. ramorum (A1 and A2 mating type) and 37 other Phytophthora spp. (71 isolates), including the recently described P. cactorum $\times$ hedraiandra hybrids (26). Also, 13 species (17 isolates) of the closely related genus Pythium were tested (Table 1). All Phytophthora spp. isolates, but also five isolates of Pythium species (Pythium intermedium, P. irregulare, P. oedochilum, P. sylvaticum, and $P$. undulatum), gave positive results in the assay. Analysis of the ITS sequences of these species shows that the primer and probe sequences are $100 \%$ identical to the corresponding regions in $P$. oedochilum. The other four cross-reacting Pythium spp. have only one mismatch with the probe. The negative results for the other five Pythium spp. tested were not caused by inhibition or inefficient DNA extraction as tested by conventional PCR with universal fungus primers ITS1 and ITS4 (41). All Pythium isolates tested gave positive results by showing amplicons, meaning that the DNA was of sufficient quality and quantity for amplification and that no inhibition of the amplification occurred.

A 10-fold dilution series starting with $10 \mathrm{ng}$ of DNA of $P$. ramorum isolate CBS 101553 (Table 1) was tested using the assay. The standard curve calculated from triplicate amplifications showed a linear response from $1 \mathrm{ng}$ down to $10 \mathrm{fg}$ (Fig. 1). To determine whether DNA from rhododendron would affect the efficiency of the assay, the dilutions also were tested in the presence of $1 \mu \mathrm{l}$ of DNA extracted from $75 \mu \mathrm{l}$ of sap of healthy rhododendron leaves. This amount of extracted plant DNA used in this experiment was the same as when field plants were sampled. The $\mathrm{Ct}$ values were very similar over the range of DNA concentrations tested in the presence or absence of rhododendron DNA.

Method comparison. We compared the performance of six diagnostic methods able to detect $P$. ramorum. Three methods allowed species identification: isolation followed by morphological examination, UCB $P$. ramorum TaqMan assay (13), and CSL $P$. ramorum TaqMan assay (15). The other three methods were ELISA (Agdia), LFD (Pocket Diagnostic), and the Phytophthora spp. TaqMan assay diagnose to Phytophthora genus. The results with all assays performed on 148 rhododendron field samples (74 leaf samples and 74 stem samples) are summarized in Table 3 (categories a to p). Each sample in a category with either a positive $P$. ramorum TaqMan result or a positive culture result for $P$. ramorum was considered to contain $P$. ramorum, resulting in a positive final diagnosis.

Comparison of overall test results. In all, 33 samples (Table 3 , category a) were positive with all tests ( $P$. ramorum-positive), whereas 61 samples (category b) were negative with all tests (no 
Phytophthora spp. present). For four samples (category c), all results were consistent with the presence of another Phytophthora sp., initially identified as $P$. cactorum (Lebert \& Cohn) J. Schröt by morphological analysis, but showing numerous abortive oospores. In a detailed study, these isolates proved to be $P$. cactorum $\times$ hedraiandra hybrids (26). This finding was confirmed by sequencing of the PCR products that were obtained with the Phytophthora spp. TaqMan assay. This results in $66 \%([33+61+$ 4]/148) concordance between all test results. Of the remaining 50 samples with discrepant test results, in 13 cases (categories d to j), the different results with the assays used were caused by the presence of another Phytophthora sp., which was P. cactorum $\times$ hedraiandra as determined by morphological analysis or sequencing. In 10 of these 13 samples (categories $d$ to h), there was co-infection of $P$. ramorum and $P$. cactorum $\times$ hedraiandra because both Phytophthora spp. were detected by $P$. ramorum TaqMan, sequencing, and culture-based identification. In 2 of these 13 samples (categories $\mathrm{d}$ and e), $P$. ramorum was detected by $P$. ramorum TaqMan, whereas culture and sequencing detected $P$. cactorum $\times$ hedraiandra. This result indicated that the other Phytophthora sp. outgrew $P$. ramorum on the agar plate and that it was present in excess over $P$. ramorum and was amplified at the cost of $P$. ramorum in the Phytophthora spp. TaqMan PCR. Of the 17 samples that contained $P$. cactorum $\times$ hedraiandra (categories c to j), 16 (categories c to i) were identified by sequencing of the PCR product, whereas only 7 (categories $c$, d, e, and j) were identified by morphological examination. Twelve samples (category k) were positive only with the ELISA.

Comparison of $\boldsymbol{P}$. ramorum TaqMan assays. Both assays (CSL and UCB) scored 57 samples (Tables 3, categories a, d, e, g, $1, \mathrm{~m}$, and $\mathrm{n}$; and 4) as positive. However, the mean difference in $\mathrm{Ct}$ value of these samples with the UCB $P$. ramorum TaqMan assay (13) was 4.3 cycles lower than that obtained with the CSL $P$. ramorum TaqMan assay (15) (mean Cts of 23.1 and 27.4 for UCB and CSL $P$. ramorum TaqMan assays, respectively; 95\% confidence interval 3.7 to $4.9 ; P<0.001$, two-tailed paired Student's $t$ test) corresponding to an $\approx 20$-fold higher analytical sensitivity for the UCB $P$. ramorum TaqMan assay (data not shown).

Comparison of DNA extraction methods. To determine whether the DNA isolation method influenced the results of the amplifications, we compared TaqMan results from DNA isolated using the standard method (i.e., the column-based Qiagen DNeasy Plant DNA extraction method) with those from DNA isolated using a magnetic bead-based method, the QuickPick Plant DNA Kit from Bio-Nobile, using the KingFisher 96 magnetic particle processor. The QuickPick Plant DNA isolation method was performed on plant sap aliquots from 137 of the 148 rhododen-

TABLE 3. Comparison of results of enzyme-linked immunosorbent assay (ELISA), lateral flow device (LFD), TaqMan assays, and culture-based morphology for 148 Rhododendron field samples

\begin{tabular}{|c|c|c|c|c|c|c|c|c|c|c|}
\hline \multirow[b]{2}{*}{ Cat. $^{\mathrm{a}}$} & \multirow[b]{2}{*}{ No. ${ }^{b}$} & \multirow[b]{2}{*}{ ELISA } & \multirow[b]{2}{*}{ LFD } & \multicolumn{4}{|c|}{ TaqMan assays $^{\mathrm{c}}$} & \multirow[b]{2}{*}{ Isolation $^{\mathrm{f}}$} & \multirow[b]{2}{*}{ Morphology } & \multirow[b]{2}{*}{ Diagnosis ${ }^{\mathrm{g}}$} \\
\hline & & & & Phyto $^{\mathrm{d}}$ & Sequencing amplicon ${ }^{\mathrm{e}}$ & UCB & CSL & & & \\
\hline $\mathrm{a}$ & 33 & + & + & + & $\mathrm{Nd}$ & + & + & + & P. ramorum & Positive \\
\hline $\mathrm{b}$ & 61 & - & - & - & $\mathrm{Na}$ & - & - & - & $\mathrm{Na}$ & Negative \\
\hline $\mathrm{c}$ & 4 & + & + & + & P. cacto $\times$ hedr & - & - & + & P. cacto $\times$ hedr & Negative \\
\hline d & 1 & + & + & + & $P$. cacto $\times$ hedr and $P$. ramorum & + & + & + & P. cacto $\times$ hedr & Positive \\
\hline $\mathrm{e}$ & 1 & + & + & + & P. cacto $\times$ hedr & + & + & + & P. cacto $\times$ hedr & Positive \\
\hline f & 6 & + & + & + & P. cacto $\times$ hedr & - & - & + & $P$. ramorum & Positive \\
\hline $\mathrm{g}$ & 1 & - & + & + & P. cacto $\times$ hedr & + & + & + & P. ramorum & Positive \\
\hline $\mathrm{h}$ & 1 & - & + & + & P. cacto $\times$ hedr & - & - & + & P. ramorum & Positive \\
\hline $\mathrm{i}$ & 2 & + & + & + & P. cacto $\times$ hedr & - & - & - & $\mathrm{Na}$ & Negative \\
\hline $\mathrm{j}$ & 1 & - & - & - & $\mathrm{Na}$ & - & - & + & P. cacto $\times$ hedr & Negative \\
\hline $\mathrm{k}$ & 12 & + & - & - & $\mathrm{Na}$ & - & - & - & $\mathrm{Na}$ & Negative \\
\hline 1 & 18 & + & + & + & $\mathrm{Nd}$ & + & + & - & $\mathrm{Na}$ & Positive \\
\hline $\mathrm{m}$ & 2 & + & - & + & $\mathrm{Nd}$ & + & + & - & $\mathrm{Na}$ & Positive \\
\hline $\mathrm{n}$ & 1 & - & - & + & $\mathrm{Nd}$ & + & + & - & $\mathrm{Na}$ & Positive \\
\hline o & 1 & + & + & - & $\mathrm{Na}$ & - & - & + & P. ramorum & Positive \\
\hline $\mathrm{p}$ & 3 & - & - & - & $\mathrm{Na}$ & - & - & + & P. ramorum & Positive \\
\hline
\end{tabular}

a Sample category.

${ }^{\mathrm{b}}$ Number of samples.

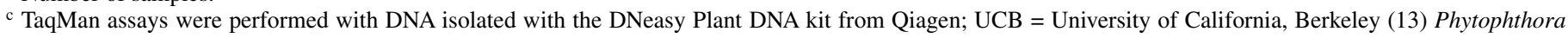
ramorum; CSL = Central Science Laboratory, York, UK (15) P. ramorum; $\mathrm{Na}=$ not applicable; and $\mathrm{Nd}=$ not done.

d Phytophthora spp., this study.

e Sequencing Phytophthora spp. amplicon. P. cactorum $\times$ hedraiandra $($. cacto $\times$ hedr) is a recently described hybrid (26).

f Isolation of Phytophthora spp.

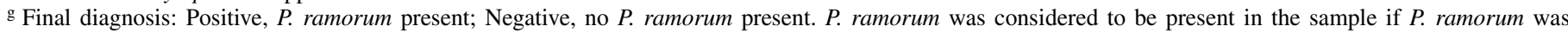
isolated or if at least one of the $P$. ramorum TaqMan assays was positive.

TABLE 4. Calculation and comparison of diagnostic values of enzyme-linked immunosorbent assay (ELISA), lateral flow device (LFD), TaqMan assays, and culture-based morphology for Phytophthora ramorum detection in 148 Rhododendron field samples (prevalence $42 \%)^{\mathrm{a}}$

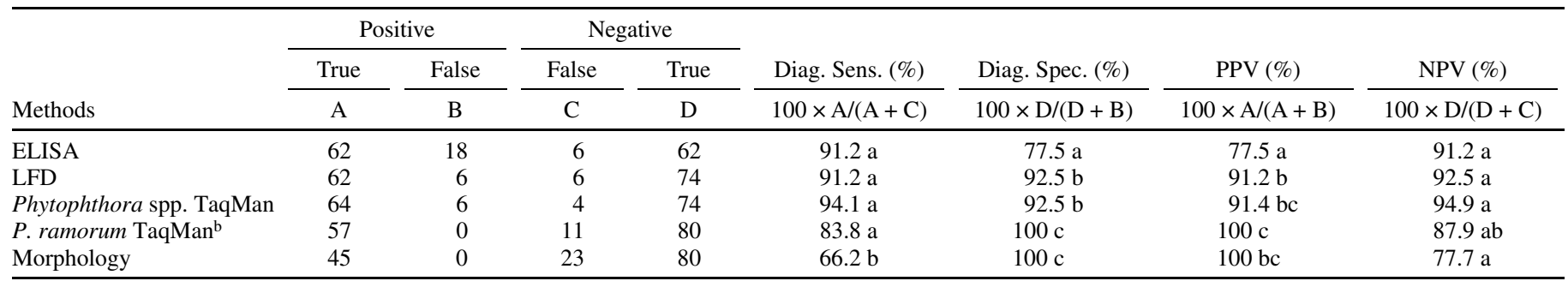

${ }^{a}$ Diag. Sens. $=$ diagnostic sensitivity, Diag. Spec. $=$ diagnostic specificity, PPV = positive predictive value, and NPV = negative predictive value. Values followed by a different letter in a column are significantly different $(P=0.05)$ according to Fisher's exact test (two-tailed) (17).

${ }^{\mathrm{b}}$ Results with Central Science Laboratory, York, UK (15) and University of California, Berkeley (13) P. ramorum assays were identical. 
dron test samples that were used for the DNeasy DNA isolation method. The samples were amplified using the UCB $P$. ramorum TaqMan assay routinely used for $P$. ramorum detection in our lab. The results of this experiment are shown in Figure 2A and B. A total of 48 samples scored positive with the DNeasy Plant DNA extraction method. These 48 samples and 2 additional samples were positive using the QuickPick Plant DNA isolation method. For the two samples positive only with the QuickPick Plant DNA isolation method, the corresponding DNeasy $\mathrm{Ct}$ results were 37.2 and 39.0, which were scored negative because they were in excess of the cut-off $\mathrm{Ct}$ value of 35 . The mean Cts of the two methods were calculated with the $\mathrm{Cts}$ of the 50 samples that were positive with both methods. The mean Cts were 23.7 and 22.1 for DNeasy and QuickPick, respectively. The 1.6 cycles lower $\mathrm{Ct}$ value $(95 \%$ confidence interval 1.0 to $2.2 ; P<0.001$, two-tailed paired Student's $t$ test) for the QuickPick method corresponded to a twofold lower detection limit. To demonstrate the importance of the purity of the DNA on the amplification efficiency, we also performed the UCB $P$. ramorum TaqMan assay on DNA samples obtained with the QuickPick kit, but with the PVPP purification step omitted (Fig. 2A and B). The number of positives decreased from 50 to 38, with an increase of 7.6 cycles in $\mathrm{Ct}$ value $(95 \%$ confidence interval 5.9 to $9.3 ; P<0.001$, two-tailed paired Student's $t$ test) (200-fold higher detection limit compared with PVPP) of Ct values from 22.1 to 29.7 , demonstrating the benefit of DNA purification.

Comparison of $P$. ramorum TaqMan assays and culturebased morphological identification. In all, 34 samples (Table 3, categories a and $\mathrm{g}$ ) tested positive for $P$. ramorum by both
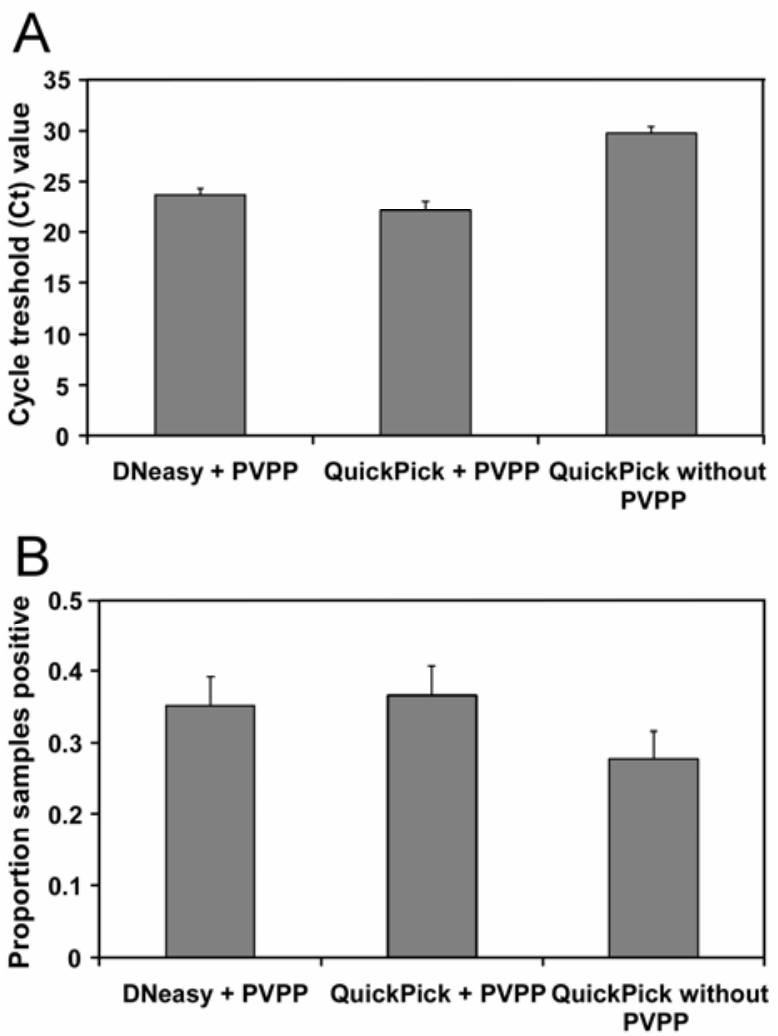

Fig. 2. Comparison of DNA extraction methods. DNA was isolated from 137 rhododendron samples using the Qiagen DNeasy DNA isolation kit and the Bio-Nobile QuickPick DNA isolation kit using the KingFisher system, with and without polyvinylpolypyrrolidone (PVPP) purification. The efficiency of DNA extraction was measured by performing the University of California, Berkeley Phytophthora ramorum TaqMan assay (13). The results are expressed in $\mathbf{A}$, cycle threshold $(\mathrm{Ct})$ values and $\mathbf{B}$, proportion of samples with a positive polymerase chain reaction result. Error bars represent standard errors of means (A) and proportions (B).
P. ramorum-specific TaqMan and culture-based morphological identification, and 80 samples (categories b, c, i, j, and k) were negative with both methods, resulting in a concordance of $77 \%$ $([34+80] / 148)$. In all, 23 samples (categories d, e, 1, m, and n) were positive for $P$. ramorum with TaqMan only; 2 of these 23 (categories $\mathrm{d}$ and e) contained not only $P$. ramorum but also $P$. cactorum $\times$ hedraiandra as identified by morphological analysis and sequencing, whereas 11 (categories $\mathrm{f}, \mathrm{h}, \mathrm{o}$, and $\mathrm{p}$ ) were $P$. ramorum positive with culture only. An explanation for these 11 false-negative $P$. ramorum TaqMan results is that the amount of DNA used for the TaqMan assay corresponded to a 40-fold smaller volume of plant parts than used by isolation $\left(0.025 \mathrm{~cm}^{2}\right.$ versus $2 \mathrm{~cm}^{2}$ ). To investigate whether $\mathrm{Ct}$ values are good predictors for viability of $P$. ramorum, we compared $P$. ramorum TaqMan Ct values (UCB assay) of samples from which $P$. ramorum was cultured and from samples where $P$. ramorum was not recovered by culture. The mean $\mathrm{Ct}$ values of the 23 P. ramorum TaqMan-positive (UCB assay), culture-negative samples was 23.8, whereas the mean $\mathrm{Ct}$ of the 34 P. ramorum TaqMan- and culture-positive samples was 22.6 (least significant difference $=$ 1.7 [at $\alpha=0.05$ ]; $P=0.15$, two-tailed unpaired Student's $t$ test). Thus, it was not possible to predict viability of $P$. ramorum based on $\mathrm{Ct}$ values.

Accuracy of tests. The accuracy of each test for detection of P. ramorum was analyzed by calculating the diagnostic sensitivity, diagnostic specificity, PPV, and NPV (Table 4). We defined a sample with either a positive $P$. ramorum TaqMan result or positive $P$. ramorum culture result as a true positive result. The method with the highest calculated diagnostic sensitivity for detection of P. ramorum was the Phytophthora spp. TaqMan assay $(94.1 \%)$, followed by ELISA and LFD (both 91.2\%), P. ramorum TaqMan assay $(83.8 \%)$, and culture-based morphological identification (66.2\%). The differences in diagnostic sensitivity of ELISA, LFD, and TaqMan assay for detection of Phytophthora spp. were not statistically significant, whereas culture-based morphological identification was significantly less sensitive than the other methods. The PPVs and NPVs shown in Table 4 are only valid for this experimental population, with a prevalence of $42 \%$. To demonstrate the effect of prevalence on the predictive values, estimations of these parameters at different chosen prevalences were assessed (Tables 5 and 6). Negative predictive values for all assays were $>95 \%$ at prevalence $<10 \%$. At a prevalence of $1 \%$, NPVs were $>99.5 \%$.

\section{DISCUSSION}

Thus far, no comparisons of immunological with both molecular and morphological methods for detection of $P$. ramorum have been published. In this article, all types of assays currently in use for detection of $P$. ramorum were compared. Three Phytophthora spp. assays detect all Phytophthora spp.; however, none is genus specific. This study shows that the Phytophthora spp. TaqMan assay detects several Pythium spp., and the antibodies used for ELISA and LFD cross-react with several Pythium spp. (Neogen Corporation) (34). The manufacturer of the ELISA kit reports cross-reactivity with 10 of 19 species tested (Agdia). Nevertheless, because all generic assays have higher diagnostic sensitivities than the $P$. ramorum-specific assays (Table 4), they are suitable to be used as a first screen, where a positive result should be confirmed with a method that is specific for $P$. ramorum.

All generic methods had similar diagnostic sensitivities for P. ramorum detection: $94.1 \%$ for the Phytophthora spp. TaqMan and $91.2 \%$ for both ELISA and LFD. An evaluation study of LFDs used at the site of inspection reports a comparable diagnostic sensitivity of $87.6 \%$ (22). The diagnostic sensitivities of the two $P$. ramorum-specific TaqMan assays $(83.8 \%)$ both were significantly higher than that of culture-based morphological identification (66.2\%). This difference between PCR and culture is 
comparable to the observed difference between conventional PCR and culture as demonstrated in a previous study with 129 field samples (19) with sensitivities of 92 and $78 \%$, respectively. The low diagnostic sensitivity of culturing could be due to unfavorable environmental conditions because the samples were taken in August and September 2005, during the dry period in The Netherlands. Furthermore, our study shows that, in case of co-infection with another Phytophthora sp., culturing can fail to detect $P$. ramorum-positive samples. Molecular identification methods can be used for large-scale testing.

ELISA reagents are cheap $(<\$ 0.5$ per sample) and relatively easy to perform and their 96 -well format makes them suitable for large-scale prescreening, especially when the assay is automated on a robotic workstation. Compared with ELISA, LFD reagents are more expensive $(\$ 15)$ and cost very little to perform but are not suitable for large-scale testing. Their strength is that they are rapid and robust and can be used outside the laboratory. In the United Kingdom, LFDs are being used by Plant Health and Seeds Inspectorate field inspectors of the Department of Environment, Food and Rural Affairs and by woodland officers of the Forestry Commission for monitoring for P. ramorum and P. kernoviae (22). The Phytophthora spp. TaqMan assay was tested and also included in the comparisons to solve discrepancies between ELISA, LFD, P. ramorum TaqMan, and culturing because Phytophthora spp. can be identified by sequence analysis of the PCR product. The assay has no additional value as a screening method when the target of interest is only $P$. ramorum, because the costs are the same as those of the specific $P$. ramorum TaqMan assays $(\approx \$ 5)$ plus the cost of sequencing (\$30). However, when diagnosis of all Phytophthora spp. is necessary, the Phytophthora spp. TaqMan is useful.

In six samples, the Phytophthora spp. TaqMan and LFD detected $P$. cactorum $\times$ hedraiandra. The same six samples also were positive with ELISA. Twelve additional samples were positive with ELISA, whereas no Phytophthora spp. were detected using other methods. For these samples, cross-reactivity of the antiserum with Pythium spp. cannot be excluded. For prescreening tests, both high sensitivity and high NPVs are important because reliability of negative results is very important. The
NPVs of all generic assays were higher than those of the specific assays, although, at low prevalence, the values were very close. For example, at a prevalence of $1 \%$, the NPVs of ELISA and morphological identification were 0.999 and 0.997 .

Real-time PCR can be performed in a 96-well format; however, when performing column-based DNA extraction methods like the DNeasy kit, DNA isolation becomes the rate-limiting step, because only 12 to 24 samples can be processed simultaneously. In this study, we showed that automation of nucleic acid extraction using the KingFisher 96 system, where 96 samples can be processed simultaneously, gives excellent results (Fig. 2) and reduces sampling handle time. Not only were $\mathrm{Ct}$ values 1.6 cycles lower for the KingFisher method compared with the DNeasy method tested on 137 samples but, in addition, two more positive samples also were detected, which increased the diagnostic sensitivity from 82.2 to $86.2 \%$. We also showed that purification of DNA with PVPP improves amplification because Cts increased by 7.6 cycles and the diagnostic sensitivity decreased to $65.5 \%$ when the PVPP purification was omitted.

We compared the results of two $P$. ramorum-specific TaqMan assays to examine whether the choice of assay influenced the results with respect to the diagnostic sensitivity and $\mathrm{Ct}$ values. There was no difference in diagnostic sensitivity between both methods, although the mean $\mathrm{Ct}$ of samples tested with the CSL $P$. ramorum TaqMan assay was 4.3 cycles higher (corresponding to a 20-fold increase in detection limit) compared with that of the UCB $P$. ramorum TaqMan assay. This difference in $\mathrm{Ct}$ values reflects the difference in detection limit of both assays. The UCB $P$. ramorum TaqMan assay has a detection limit of $50 \mathrm{fg}$ of template DNA (13); the CSL $P$. ramorum TaqMan assay has a 100 -fold lower detection limit of $5 \mathrm{pg}$ of DNA (15). The original CSL $P$. ramorum TaqMan assay, designed with a different forward primer $(114 \mathrm{~F}$ instead of $114 \mathrm{Fc})$, has a detection limit comparable with that of the UCB P. ramorum TaqMan assay, $100 \mathrm{fg}$ of template DNA; however, cross-amplification occurred with cultures of $P$. lateralis Tucker \& Millbrath, the close relative to $P$. ramorum based on molecular phylogeny (40). Therefore, a nucleotide change at the $3^{\prime}$ position was introduced to make the primer sequence more distinct from the ITS target sequence of $P$. lateralis.

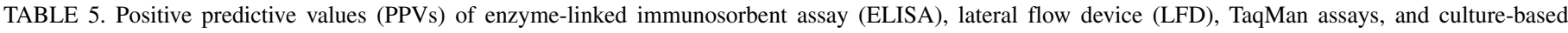
morphological identification for Phytophthora ramorum detection at different prevalences ${ }^{\text {a }}$

\begin{tabular}{|c|c|c|c|c|c|}
\hline Prevalence & ELISA & LFD & Phytophthora spp. TaqMan & P. ramorum TaqMan ${ }^{\text {b }}$ & Morphology \\
\hline 0.05 & 0.176 & 0.390 & 0.398 & 1.00 & 1.00 \\
\hline 0.10 & 0.310 & 0.575 & 0.582 & 1.00 & 1.00 \\
\hline 0.20 & 0.503 & 0.752 & 0.759 & 1.00 & 1.00 \\
\hline 0.46 & 0.775 & 0.912 & 0.914 & 1.00 & 1.00 \\
\hline 0.60 & 0.859 & 0.948 & 0.949 & 1.00 & 1.00 \\
\hline 0.80 & 0.942 & 0.980 & 0.980 & 1.00 & 1.00 \\
\hline 0.90 & 0.973 & 0.991 & 0.991 & 1.00 & 1.00 \\
\hline
\end{tabular}

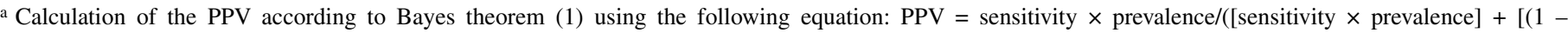
specificity) $\times(1-$ prevalence $)])$.

b Results with Central Science Laboratory, York, UK (15) and University of California, Berkeley (13) P. ramorum assays were identical.

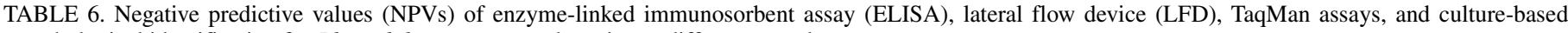
morphological identification for Phytophthora ramorum detection at different prevalences ${ }^{\mathrm{a}}$

\begin{tabular}{|c|c|c|c|c|c|}
\hline Prevalence & ELISA & LFD & Phytophthora spp. TaqMan & P. ramorum TaqMan ${ }^{\mathrm{b}}$ & Morphology \\
\hline 0.01 & 0.999 & 0.999 & 0.999 & 0.998 & 0.997 \\
\hline 0.05 & 0.994 & 0.995 & 0.997 & 0.992 & 0.983 \\
\hline 0.10 & 0.988 & 0.990 & 0.993 & 0.982 & 0.964 \\
\hline 0.20 & 0.972 & 0.977 & 0.984 & 0.961 & 0.922 \\
\hline 0.46 & 0.912 & 0.925 & 0.949 & 0.879 & 0.777 \\
\hline 0.60 & 0.854 & 0.875 & 0.913 & 0.805 & 0.663 \\
\hline 0.80 & 0.687 & 0.724 & 0.797 & 0.607 & 0.425 \\
\hline
\end{tabular}

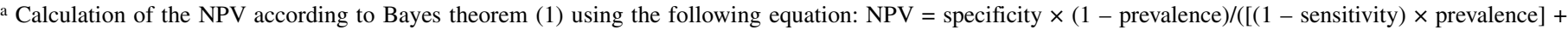
[specificity $\times(1-$ prevalence $)])$.

b Results with Central Science Laboratory, York, UK (15) and University of California, Berkeley (13) P. ramorum assays were identical. 
When a nested approach was used for the UCB $P$. ramorum TaqMan assay, Hayden and coworkers (14) reported a 3.3-fold lower detection limit (15 fg of DNA) compared with the singleround approach (50 fg of DNA) used in this study. No crossreaction with $P$. lateralis was reported in their study. Even though the authors report almost threefold higher positive scores with the nested approach, we did not choose this approach because nested PCRs are very prone to contamination with amplification products, because of the high number of molecules ( $>10^{12}$ per reaction) produced in an amplification reaction. In our study, we found identical positive rates with two assays with a reported 100-fold difference in detection limit. When working with non-PVPPpurified DNA, we found a dramatic decrease of sensitivity (analytical and diagnostic), demonstrating that the purity of DNA has more effect on the efficiency of PCR than the detection limit. A similar effect for DNA extractions from other plant species has been demonstrated by Martin et al. (24). Using the PVPP purification, there is no need to use diluted DNA extract prior to amplification. Dilution of DNA is a common practice in cases where the quality of the DNA is insufficient. Hayden and coworkers used 100-fold diluted DNA extracts from plants; the need to dilute the DNA indicated the presence of inhibitors in the DNA extract, even though purified DNA was used (Geneclean Turbo Nucleic Acid Purification Kit; Qbiogene). The plant material used in their study included wood and comprised several hosts, whereas our study was performed with leaves and stems of Rhododendron only. The authors showed that nested TaqMan performs better than single-round TaqMan using DNA extracted from Lithocarpus densiflorus. These data support our finding that quality of DNA is more critical for successful amplification than the detection limit of the PCR.

We conclude that the diagnostic values of ELISA, LFD, and the Phytophthora spp. TaqMan assay make these methods suitable as prescreening methods. Samples with a negative result in the prescreening assay can be diagnosed as negative, whereas positives must be confirmed using additional specific methods. The prescreening approach can be very efficient when negatives are expected, such as when monitoring plants in the nursery trade. The broad screen also allows detection of other (new) Phytophthora spp. In test populations with a high prevalence, such as at a known outbreak site, it is more efficient to omit prescreening and use a method that is specific for $P$. ramorum. Both molecular and culture-based morphological identification are approved methods for identification of $P$. ramorum. Because both PCR and culture have lower sensitivities than ELISA, it will not always be possible to confirm ELISA-positive results with these methods. In such cases, additional samples have to be investigated. In critical situations (e.g., in the case of a first finding on a new host or site), it is advisable to rely on both a $P$. ramorum TaqMan assay and a culture. For routine testing, in most cases, it will be sufficient to rely on the TaqMan results.

\section{ACKNOWLEDGMENTS}

We thank K. J. Hayden and K. J. D. Hughes for providing us primer and probe sequences prior to publication; K. Kontu for providing us a QuickPick Plant DNA isolation protocol for the KingFisher 96; M. Al Habib, M. L. Bruil, R. A. van Hoof, J. P. Meffert, C. H. M. RosendahlPeters, M. M. J. P. van Raak, A. C. M. Tonk, E. C. P Verstappen, and M. de Weerdt for technical assistance; S. L. G. E. Burgers for statistical advice; C. R. Lane for revision regarding the use of the English language; and K. J. D. Hughes, C. R. Lane, W. A. Man in 't Veld, G. C. M. van Leeuwen, and anonymous reviewers for helpful discussions.

\section{LITERATURE CITED}

1. Altman, D. G. 1991. Practical Statistics for Medical Research, 1st ed. Chapman \& Hall, London.

2. Altman, D. G., and Bland J. M. 1994. Statistic notes: Diagnostic tests 1: sensitivity and specificity. Brit. Med. J. 308:1552.

3. Altman, D. G., and Bland J. M. 1994. Statistic notes: Diagnostic tests 2: predictive values. Brit. Med. J. 309:102.

4. Altschul, S. F., Madden, T. L., Schäffer, A. A., Zhang, J., Zhang, Z., Miller, W., and Lipman, D. J. 1997. Gapped BLAST and PSI-BLAST: A new generation of protein database search programs. Nucleic Acids Res. 25:3389-3402.

5. Bilodeau, G., Lévesque, C. A., de Cock, A. W. A. M., Kristjansson, G., McDonald, J., and Hamelin, R. C. 2003. Detection and identification of Phytophthora ramorum, the causal agent of sudden oak death by real-time PCR. (Abstr.). Phytopathology 93:S8.

6. Danks, C., and Barker, I. 2000. On-site detection of plant pathogens using lateral-flow devices. EPPO Bull. 30:421-426.

7. Dick, M. W. 1989. Phytophthora undulata comb. nov. Mycotaxon 35:449453.

8. European and Mediterranean Plant Protection Organization. 2006. Diagnostic protocol for regulated pests. Phytophthora ramorum. EPPO Bull. 36:145-155.

9. European Union. 2002. Commission Decision of 19 September 2002 on provisional emergency phytosanitary measures to prevent the introduction into and the spread within the Community of Phytophthora ramorum Werres, De Cock \& Man in 't Veld sp. nov. (2002/757/EC). Off. J. Eur. Union, Legislation Ser. 252:37-39.

10. European Union. 2004. Commission Decision of 29 April 2004 amending Decision 2002/757/EC on provisional emergency phytosanitary measures to prevent the introduction into and the spread within the Community of Phytophthora ramorum Werres, De Cock \& Man in 't Veld sp. nov. (2004/426/EC). Off. J. Eur. Union, Legislation Ser. 154:1-7.

11. Gams, W., Hoekstra, E. S., and Aptroot, A. 1998. CBS Course of Mycology, 4th ed. Centraalbureau voor Schimmelcultures, Baarn, The Netherlands.

12. Graham, J. H., and Timmer, L. W. 1994. Phytophthora diseases of citrus. Document SL127/CH087. Published online by Soil and Water Science Department, Florida Cooperative Extension Service, Institute of Food and Agricultural Sciences, University of Florida.

13. Hayden, K., Ivors, K., Wilkinson, C., and Garbelotto, M. 2006. TaqMan chemistry for Phytophthora ramorum detection and quantification, with a comparison of diagnostic methods. Phytopathology 96:846-854.

14. Hayden, K. J., Rizzo, D., Tse, J., and Garbelotto, M. 2004. Detection and quantification of Phytophthora ramorum from Californian forests using a real-time polymerase chain reaction assay. Phytopathology 94:1075-1083

15. Hughes, K. J. D., Griffin, R. L., Tomlinson, J. A., Boonham, N., Inman, A. J., and Lane, C. 2006. Development of a one step real-time PCR assay for diagnosis of Phytophthora ramorum. Phytopathology 96:975-981.

16. Ioos, R., Laugustin, L., Schenk, N., Rose, S., Husson, C., and Frey, P. 2006. Usefulness of single copy genes containing introns in Phytophthora for the development of detection tools for the regulated species $P$. ramorum and P. fragariae. Eur. J. Plant Pathol. 116:171-176.

17. Kendall, M., and Stuart, A. 1979. The Advanced Theory of Statistics. Volume 2, 4th ed. Griffins, London.

18. Kong, P., Hong, C. X., Tooley, P. W., Ivors, K., Garbelotto, M., and Richardson, P. A. 2004. Rapid identification of Phytophthora ramorum using PCR-SSCP analysis of ribosomal DNA ITS-1. Lett. Appl. Microbiol. 38:433-439.

19. Kox, L. F. F., Boxman, I. L. A., Jansen, C. C. C., and Roenhorst, J. W. 2005. Reliability of nucleic acid amplification techniques: Modified target RNA as exogenous internal standard for a real-time RT-PCR for Potato spindle tuber viroid. EPPO Bull. 35:117-124.

20. Kox, L., de Gruyter, H., Garbelotto, M., van Brouwershaven, I., Admiraal, J., and Baayen, R. 2002. Validation of a PCR method for detection and identification of Phytophthora ramorum. (Abstr.) (poster B05) Page 57-58 in: Proc. Sudden Oak Death Sci. Symp. Monterey, CA.

21. Kroon, L. P. N. M., Verstappen, E. C. P., Kox, L. F. F., Flier, W. G., and Bonants, P. J. M. 2004. A rapid diagnostic test to distinguish between American and European isolates of Phytophthora ramorum. Phytopathology 94:613-620.

22. Lane, C. R., Hobden, E., Walker, L., Barton, V. C., Inman, A. J., Hughes, K. J. D., Swan, H., Colyer, A., and Barker, I. Evaluation of a rapid diagnostic field test kit for identification of species, including $P$. ramorum and P. kernoviae at the point of inspection. Plant Pathol. (In press.)

23. Lee, L. G., Connell, C. R., and Bloch, W. 1993. Allelic discrimination by nick-translation PCR with fluorogenic probes. Nucleic Acids Res. 21:3761-3766

24. Livak, K. J., Flood, S. J., Marmaro, J., Giusti, W., and Deetz, K. 1995. Oligonucleotides with fluorescent dyes at opposite ends provide a quenched probe system useful for detecting PCR product and nucleic acid hybridization. PCR Methods Appl. 4:357-362.

25. Livak, K. J., and Schmittgen, T. D. 2001. Analysis of relative gene expression data using real-time quantitative PCR and the $2^{-\Delta \Delta C t}$ method. 
Methods 25:402-408.

26. Man in 't Veld, W. A., de Cock, A. W. A. M., and Summerbell, R. C. 2007. Natural hybrids of resident and introduced Phytophthora species proliferating on multiple new hosts. Eur. J. Plant Pathol. 117:24-33.

27. Martin, F. N., Tooley, P. W., and Blomquist, C. 2004. Molecular detection of Phytophthora ramorum, the casual agent of sudden oak death in California and two additional species commonly recovered from diseased plant material. Phytopathology 94:621-631.

28. Panabières, F., Ponchet, M., Allasia, V., Cardin, L., and Ricci, P. 1997. Characterization of border species among Pythiaceae: several Pythium isolates produce elicitins, typical proteins from Phytophthora spp. Mycol. Res. 101:1459-1468.

29. Prince, A. M., and Andrus, L. 1992. PCR: how to kill unwanted DNA. Biotechniques 12:358-360.

30. Rizzo, D. M., Garbelotto, M., Davidson, J. M., Slaugheter, G. W., and Koike, S. T. 2002. Phytophthora ramorum as the cause of extensive mortality of Quercus spp. and Lithocarpus densiflorus in California. Plant Dis. 86:205-214.

31. Roenhorst, J. W., Jansen, C. C. C., Kox, L.F.F., de Haan, E. G., van den Bovenkamp, G. W., Boonham, N., Fisher, T., and Mumford, R. A. 2005. Application of real-time RT-PCR for large-scale testing of potato for Potato spindle tuber pospiviroid. EPPO Bull. 35:133-140.

32. Sambrook, J., Fritsch, E. F., and Maniatis, T. 1989. Molecular Cloning: A Laboratory Manual. Cold Spring Harbor Laboratory Press, Cold Spring Harbor, NY.

33. Schena, L., Hughes, K. D., and Cooke, D. E. L. 2006. Detection and quantification of Phytophthora ramorum, $P$. kernoviae, $P$. citricola and $P$. quercina in symptomatic leaves by multiplex real-time PCR. Mol. Plant Pathol. 7:256-379.

34. Timmer, L. W., Menge, J. A., Zitko, S. E., Pond, E., Miller, S. A., and Johnson, E. L. V. 1993. Comparison of ELISA techniques and standard isolation methods for Phytophthora detection in citrus orchards in Florida and California. Plant Dis. 77:791-796.

35. Tomlinson, J. A., Boonham, N., Hughes, K. J. D., Griffin, R. L., and Barker, I. 2005. On-site DNA extraction and real-time PCR for detection of Phytophthora ramorum in the field. Appl. Environ. Microbiol. 71:6702-6710.

36. Tooley, P. W., Martin F. N., Carras. M. M., and Frederick, R. D. 2006. Real-time fluorescent polymerase chain reaction detection of Phytophthora ramorum and Phytophthora pseudosyringae using mitochondrial gene regions. Phytopathology 96:336-345.

37. Unites States Department of Agriculture, Animal and Plant Health Inspection Service, Plant Protection and Quarantine. 2004. Update on PPQ Diagnostics for SOD: Diagnostics procedures approved by APHIS and diagnostic analyses performed by APHIS PPQ for Phytophthora ramorum. Published online by the USDA Animal and Plant Health Inspection Service.

38. Villa, N. O., Kageyama, K., Asano, T., and Suga, H. 2006. Phylogenetic relationships of Pythium and Phytophthora species based on ITS rDNA, cytochrome oxidase II and $\beta$-tubulin gene sequences. Mycologia 98:410422.

39. Weller, S. A., Elphinstone, J. G., Smith, N. C., Boonham, N., and Stead, D. E. 2000. Detection of Ralstonia solanacearum strains with a quantitative, multiplex, real-time, fluorogenic PCR (TaqMan) assay. Appl. Environ. Microbiol. 66:2853-2858.

40. Werres, S., Marwitz, R., Man in 't Veld, W. A., de Cock, A. W. A. M., Bonants, P. J. M., de Weerdt, M., Themann, K., Ilieva, E., and Baayen, R. P. 2001. Phytophthora ramorum sp. nov., a new pathogen on Rhododendron and Viburnum. Mycol. Res. 105:1155-1165.

41. White, T. J., Burns, T., Lee, S., and Taylor, J. 1990. Amplification and direct sequencing of fungal ribosomal RNA genes for phylogenetics. Pages 315-322 in: PCR Protocols: A Guide to Methods and Applications. M. A. Innis, D. H. Gelfand, J. J. Sninsky, and T. J. White, eds. Academic Press, San Diego, CA. 